\title{
A story of her own: memory and narrative in short fiction by Margaret Laurence, Alice Munro and Margaret Atwood
}

\section{Uma história toda sua: memória e narrativa em contos de Margaret Laurence, Alice Munro e Margaret Atwood}

\author{
Carolina de Pinho Santoro Lopes ${ }^{1}$
}

\begin{abstract}
:
The objective of this paper is to analyze the interplay of narrative, memory, and identity in short stories by Canadian authors Margaret Laurence, Alice Munro and Margaret Atwood. The three works explored in the article are narratives told from the perspective of characters who delve into their own past to make sense of their present, thereby revealing the strong bond between the act of remembering and the construction of one's self.
\end{abstract}

Keywords: Canadian literature. Memory. Identity.

\section{Resumo:}

O objetivo deste artigo é analisar a interação entre narrativa, memória e identidade em contos das escritoras canadenses Margaret Laurence, Alice Munro e Margaret Atwood. As três obras exploradas neste texto são narrativas a partir da perspectiva de personagens que mergulham em seu próprio passado para compreender o presente, revelando, assim, a ligação estreita entre o ato de lembrar e a construção de si.

Palavras-chave: Literatura canadense. Memória. Identidade.

Mestre e doutoranda em Letras (Literaturas de língua inglesa) pela Universidade do Estado do Rio de Janeiro. Professora do Colégio Pedro II. 
the past and the future are both always present, present in both senses of the word, always now and always here

with us.

Margaret Laurence

We can't resist this rifling around in the past, sifting the untrustworthy evidence, [...] hanging on to threads, insisting on being joined to dead people and therefore to

life.

Alice Munro

The past no longer belongs only to those who once lived in it; the past belongs to those who claim it, and are willing to explore it, and to infuse it with meaning for those alive

today.

Margaret Atwood

Margaret Laurence (1926-1987), Alice Munro (1931-) and Margaret Atwood (1939-) are contemporary Canadian authors who excel in the short-story genre. As the epigraphs demonstrate, they also share an interest in the workings of memory and our relationship with the past, expressing both the relevance of the past and the irresistible attraction that we feel toward it. This paper will explore the role of memory in three short stories, namely Laurence's To Set Our House in Order (1970), Munro's The Progress of Love (1985) and Atwood's The Age of Lead (1991).

The ability to remember the past has been discussed by thinkers from a variety of fields since Classical Antiquity. In Theaetetus, Plato (2007, p. 25) compares the creation of memories to the active process of imprinting ideas or perceptions on wax. Aristotle (2007, p. 30) also uses the metaphor of an imprint to describe memory and refers to it as a picture recorded in our body and soul. This association between memory and visual perception is reinforced by the fact that Aristotle affirms that the act of remembering occurs through images. In addition, this philosopher 
brings memory close to imagination as he states that both belong to the same part of the soul (ARISTOTLE, 2007, p. 30).

Freud also uses the image of an inscription on a slab of wax to discuss how memory works; however, he does so in a different way. According to Freud (2007), the perceptual apparatus of our minds is composed of two layers, like a "mystic writing pad", which contains a celluloid sheet that is lifted to make the writing vanish from it and a slab of wax that keeps some marks. Our perception-consciousness is comparable to the layer that retains no permanent traces while the unconscious holds a more lasting record of our perceptions (FREUD, 2007, p. 117). Henri Bergson (2007, p. 112) considers our memories elusive since individuals are compelled to act focused on the present. In order to remember, one must distance oneself from the present, as well as "have the will to dream" (BERGSON, 2007, p. 112). Thus, both authors express a more nuanced view of memory and its association with the realm of the unconscious.

More recently, memory has been connected to the narrative act, destabilizing any idea of recollections as faithful reproductions of past events. Memory may be defined as "the construction or reconstruction of what actually happened in the past" (HUA, 2008, p. 198), which means that it involves selection, interpretation, and revision. Hence, memory is malleable and unstable, rather than a fixed record of the past. The construction of memories, closely associated with storytelling, is a way to give cohesion and establish logical relations between the number of random, disorganized facts which make up one's life (CANDAU, 2016, p. 73). This bond between remembering and narrating points to the deep relationship between memory and the construction of one's identity.

Claiming a certain identity involves creating a story of the self that gives an impression of stability and coherence between one's past and present selves. Paul John Eakin (2008, p. 2) describes telling our story as a "work of self-construction", reinforcing the connection between identity 
and narrative. Joël Candau (2016, p. 73) affirms that we recollect and retell our lives in such a way as to turn a ruptured past into a linear narrative that connects the fragments of our experiences. This author also compares the act of remembering to a taming of the past as the recollecting individual takes ownership of the past and leaves their mark upon it (CANDAU, 2016, p. 74). Annette Kuhn (2007, p. 231) points out the relevance of selection and of taking into consideration that which is not present in a narrative, stating that "narratives of identity are shaped as much by what is left out of the account - whether forgotten or repressed - as by what is actually told". Forgetting may, in fact, work as an unconscious strategy for self-preservation, releasing the individual from memories that might make the past unbearable (CANDAU, 2016, p. 72).

Eakin (2008, p. 2) also states that "there is a mutually enhancing interplay between what we are and what we say we are", in other words, our experiences influence our self-narrative, and the stories we tell about ourselves have an effect on the way we understand our identity. Candau (2016, p. 75) also highlights the impact of the present on one's memories as the individual's current position may change their perspective on past events. Hence, there is no possible coincidence between the person who lived the narrated events and the person who remembers and retells them (CANDAU, 2016, p. 75). This idea is especially pertinent to the analysis of narratives told from the point of view of an older individual who recounts experiences from their youth, which is the case of the short stories explored in this paper.

Margaret Laurence (born Jean Margaret Wemyss) started her career as a writer with the publication of books connected to her experience of living in Africa for almost a decade. Later, Laurence published a series of works set in the fictional town of Manawaka, such as The Stone Angel (1964), A Bird in the House (1970), and The Diviners (1974). Laurence was born and grew up in the small Canadian town of Neepawa, which 
contributed to the creation of Manawaka. She also drew upon her experience of being raised by Presbyterian grandparents with a Scottish background, as well as upon her desire to leave their house as a young girl (BENNET; BROWN, 2010).

To Set Our House in Order, the short story that will be analyzed here, was published in A Bird in the House. The book is composed of a series of interrelated short stories that retell the childhood and adolescence of the protagonist Vanessa MacLeod. To Set Our House in Order recounts the period of Vanessa's brother's birth when she was a young girl. The stories are narrated in the first person by an older Vanessa, which may be observed in the following quotation from To Set Our House in Order: "The stern man [in the painting] was actually the Duke of Wellington, but at the time I believed him to be my grandfather MacLeod, still keeping an eye on things" (LAURENCE, 2010, p. 611, emphasis added). Thus, the story dramatizes not only the character's attempt to understand and come to terms with her past, but also the construction of a narrative of her own identity.

Vanessa learns about her family's past both through her own experience and through fragments retold by her relatives. For instance, she has conversations about her grandparents with her father and her aunt Edna. The fact that the girl's understanding of the past relies on other people's memories may be related to Maurice Halbwachs's (2006, p. 30) idea that we are never alone since we carry others' ideas and narratives. Vanessa's perception of her relatives is influenced by what other people tell her about them. It means that her mind is not a clean slate upon which memories are inscribed. Another example of this is when the girl eavesdrops her mother, Beth, telling her aunt Edna about the relationship between her father and uncle Roderick even though the conversation happens behind closed doors. The passage makes it clear that Roderick's death in World War I is a taboo for the family. Ewen, Vanessa's father, reluctantly talks about it to his wife 
only after his mother shows her the letter he wrote about it. The secrecy surrounding the subject may be related to Kuhn's affirmative that secrets are commonplace in family groups and that they may be "a necessary condition" of the stories that we recount about ourselves (KUHN, 2007, p. 230-231).

The short story is marked by the strong presence of characters who are already dead, such as grandfather MacLeod, uncle Roderick, and Vanessa's stillborn sister. As Vanessa, worried about the complications in her mother's labor, looks for hidden spots in the house, she describes the feeling of being surrounded by these people: "the unseen presences in these secret places I knew to be those of every person, young or old, who had ever belonged to the house and had died, including Uncle Roderick who got killed on the Somme, and the baby who would have been my sister" (LAURENCE, 2010, p. 611). In the same paragraph, the presence of her grandfather in the house is described as "more tangible" since Vanessa believes that he is the man portrayed in the painting hanging at the top of the stairs (LAURENCE, 2010, p. 611). Hence, Vanessa's grandmother's house, where the narrator lives with her parents, is also inhabited by the memories of those who came before, highlighting the lasting presence of the past in the family's life.

In addition to Vanessa's memories, Laurence deals with how other characters relate to their past. Grandmother MacLeod, for instance, deludes herself by pretending to live in a golden past, untouched by the repercussions of the economic depression. As she intends to have her house as well kept as before the crisis, she hires a housekeeper even though the family cannot afford to pay her. Besides, she tries to maintain distinctly ladylike manners and constructs the idea of an aristocratic origin for her family, claiming that "[t]he MacInnes is a very ancient clan, the lairds of Morven and constables of the Castle of Kinlochaline" (LAURENCE, 2010, p. 613). Grandmother MacLeod even gives Vanessa a book about 
the history of the Scottish clans and is proud of the MacInnes motto, "pleasure arises from work" (LAURENCE, 2010, p. 613-614). However, her narrative is denied by Edna, who tells Vanessa that her grandmother is the daughter of a horse doctor and should not look down upon Edna and Beth's Irish family (LAURENCE, 2010, p. 615). Vanessa's father attributes his mother's escapist behavior to her frustrated dream of being a lady, which would prevent her from acknowledging the uncomfortable financial situation experienced by the family.

This complex relationship with the past, engendered by thwarted dreams, is not exclusive to Grandmother MacLeod. Ewen talks to Vanessa about his dream of joining the merchant marine when he was a child. He projects his own experience on to his father's life, assuming that Grandfather MacLeod may have held a foiled desire to become a classical scholar. Ewen goes on to suggest that both he and his father were constrained by social expectations to follow their fathers' path by becoming doctors (LAURENCE, 2010, p. 616). Thus, there would be a family legacy of letting others' will interfere and limit one's choices. Both men's dreams leave material traces in the house: there is an analogy between the passage in which Ewen shows Grandfather MacLeod's copy of Antigone, in Greek, to his daughter and the one in which Vanessa explores her father's collection of travel literature and National Geographic magazines (LAURENCE, 2010, p. 616-617). In this way, the presence of marks from the past is tangible in the short story.

The impact of the past on characters' actions and feelings is strongly perceived throughout the story. A clear example of this is the fear and apprehension felt by Vanessa and her father in relation to Beth's labor due to her previous experience of a stillbirth. The influence of memory, though, is most striking when it comes to the manner in which different family members cope with Roderick's death. Although Grandmother MacLeod tries to look resigned and strong, it is possible to observe how 
much this loss affected her. She tells Vanessa "[w]hen your Uncle Roderick got killed, [...] I thought I would die. But I didn't die" and dismisses the girl's worries about her mother by saying that one's death is God's will (LAURENCE, 2010, p. 612-613). However, she still keeps several photos of Roderick in her bedroom, has bouts of migraine and asks Ewen to name his son after his brother. These facts demonstrate that she did not reconcile herself to her son's death as well as she tries to show.

As for Ewen, he avoids talking about his brother and seems to be ill at ease when he is forced to do that. For example, when his mother asks him to give Roderick's name to his child, Ewen states, at first, that he would prefer not to do that and then laughs and jokes about it after agreeing to comply with her wishes. According to Beth, Ewen seems to blame himself for his brother's death since he was responsible for Roderick's losing the sight of one eye, and also because he asked to have his brother in the same company as him in the army (LAURENCE, 2010, p. 618-619). Beth even suggests that her husband's experience in the war contributed to his decision to become a doctor. Even though Ewen's point of view is not clearly expressed, probably due to his discomfort with the subject, it is perceptible that he has trouble dealing with his loss. The naming of the newborn baby as Roderick may be understood as a symbol of the endurance of the past in the present.

It is important to take into consideration the possible reasons for older Vanessa to remember and recount these events. The narrator concludes the text by recalling the losses and frustrations experienced by her family members, which lead her to think that "whatever God might love in this world, it was certainly not order" (LAURENCE, 2010, p. 620). Thus, life is not an organized and polished narrative, but a series of fortuitous and sometimes painful events. Vanessa's attempt to put some order into these recollections may be seen as a way to have a better understanding of her family and her relationship with them. To an extent, she shows signs of 
constructing a more nuanced and forgiving view of her grandmother's flaws. Vanessa affirms that she does not feel at home at her grandmother's house and complains when her father says that they should be nice to her (LAURENCE, 2010, p. 611, 617). However, throughout the narrative, the intensity of Grandmother MacLeod's pain and grief is noticeable. Even when annoyed by her insistence that the baby should be named Roderick, Vanessa admits that "[a]ll at once, her feelings for that unknown dead man became a reality for me" (LAURENCE, 2010, p. 618). Moreover, the narrative includes a conversation between Vanessa and her father in which she acknowledges her grandmother's thwarted hopes, apparently for the first time, and admits that she had not thought about that before (LAURENCE, 2010, p. 617). Hence, the older Vanessa's narrative may also be considered a way to atone for her previous lack of empathy.

Alice Munro was born Alice Laidlaw in Wingham, a small community in Ontario, Canada. The experience of growing up there informs her writing, which is mostly set in small towns in this province, places where, according to Munro, 'you have no privacy at all. You have a role, a character, but one that other people have made up for you. Other people have already made your self' (BRUCKNER, 2006, online). Another important theme in Munro's fiction, which is also inspired by her own life, is the relationship between mother and daughter, a frequent topic in the works of woman authors, according to Elaine Showalter (apud FRANCESCONI, 2009, p. 344). The Progress of Love, the story under analysis here, is an example of text that deals with this bond.

The Progress of Love is narrated in first-person by Euphemia, who prefers to be called Fame. As she recounts several memories of her family, the story is characterized by shifts in time. The narrator focuses mostly on the summer of her aunt Beryl's visit, which sheds new light on a story told by Fame's mother about their mother's possible suicide attempt when they were young. However, in addition to this summer, when Fame was 
twelve, the narrative also makes reference to several events that happen to an adult Fame. In this way, past and present seem intertwined as the narrator moves between different moments in the past and, at the same time, inserts comments about the present. For instance, after talking about the inn where Beryl takes the family for lunch one day, Fame adds that "[t]oday the same building is covered with stucco and done up with Tudor beams and called the Hideaway" (MUNRO, 2010, p. 693), reinforcing the changes engendered by the passage of time. This may be related to Aristotle's (2007, p. 29) notion that time and change are "interrelated continua" since it also emphasizes the idea of time as necessarily bringing transformations.

Memory is strongly related to space in the short story, demonstrating the strength of the past in Fame's life. As an adult, she settles in the town close to where she grew up and even pays a visit to the farm where she was born. Whereas these facts suggest an attachment to an unescapable past, they also highlight the transience of the places around us. For example, the inn mentioned before turned from a fancy hotel, where Fame almost never went, into the Hideaway, a place that holds strip shows and where she goes for birthdays and other special occasions (MUNRO, 2010, p. 697). The farm where her parents lived was sold and transformed into a hippie commune, and afterwards it was bought by a couple from Ottawa. Both sales brought changes to the farm to the point that Fame is told that she would not recognize the place if she saw it again (MUNRO, 2010, p. 697).

Moreover, the story makes it clear that a person's perception may also undergo transformations as time goes by. Fame says that, when she was a child, the farm seemed to be farther from the town where she lives (MUNRO, 2010, p. 698). This impression may be related to the fact that she was not used to leaving the farm as a child, making a trip to town something awe-inspiring. Besides, it was the distance between the farm and the town school, along with the non-existence of school buses, that 
made it impossible for her to attend high school (MUNRO, 2010, p. 686). This probably made her perceive the distance as larger than it actually was.

In The Progress of Love, memory is represented more in terms of a narrative than a mental imprint. The day when Fame's mother, Marietta, finds her own mother with a rope around her neck in the cellar is recounted twice in the story, each time from a different point of view. The first version is narrated in the third person by Fame, who states that " $\mathrm{t}]$ hat was what I always heard my mother say", making it clear that she is repeating what she remembers of her mother's narrative (MUNRO, 2010, p. 690). Fame also suggests that there are some blanks and unclear points in her mother's stories as she always has the impression of something "swelling out behind" them (MUNRO, 2010, p. 690). Marietta affirms, for instance, that "[h]er heart was broken" on that day; however, she never explains exactly why, "sealing [the story] shut", according to Fame (MUNRO, 2010, p. 690).

While this memory deeply affects Marietta, Beryl takes it as a joke. She believes that their mother was only trying to scare or annoy their father and would not have really committed suicide. Although Beryl says that she noted that the other end of the rope was not tied to the beam, which would make it impossible for their mother to hang herself, Marietta still does not believe her, affirming that their mother's attitude should be taken more seriously (MUNRO, 2010, p. 696). There seems to be a mutual influence between the difference in their interpretations of this incident and their relationship with their father. Whereas Beryl seems to have a positive opinion of him, Marietta refuses to live with him after their mother's death and holds a profound resentment toward him. Beryl's version may also have been influenced by their father's since, although she claims to remember it, she affirms that their father has told her "all about it" (MUNRO, 2010, p. 695). As their mother's gesture was supposedly a way to avenge herself for their father's possible interest in another woman, 
representing her behavior as a joke would make him look better than believing she would really do it.

It is interesting to take into consideration Fame's perspective on these two versions of the same event. At first, she thinks that it is normal for Beryl's story to be distinct from her mother's since they were very different people. Her description that "everything about [Beryl] was slanted, seen from a new angle" (MUNRO, 2010, p. 696) suggests her preference for her mother's version due to the frequently negative connotation of the word "slanted". Fame herself affirms that she gave more credit to her mother's story "for a time" (MUNRO, 2010, p. 696). Even her narrative choices reveal this preference since Marietta's story is narrated in third person, suggesting an impartial perspective, while Beryl's is recounted in first person and is explicitly her own speech. However, as the narrator puts it, her aunt's version does not disappear, that is, it is impossible to forget that her mother's recollection is not the absolute truth, which fictionally illustrates Kuhn's (2007, p. 233) statement that digging one's family's memory "reveal[s] not ultimate truth, but greater knowledge".

This malleable aspect of memory is also present in Fame's account of the fate of the legacy left by her grandfather to her mother. The first time the story is narrated, Fame tells Bob Marks, a friend and apparent romantic interest, that her father watched as her mother burned the money in the stove. However, Fame then explains to the reader that, when Marietta reveals what she did to the inheritance during Beryl's visit, her father looks surprised and that her mother mentions that no one was at home at that moment. Consequently, Fame concludes that "it seems fairly clear, if I remember everything, that he did not know about it until that Sunday afternoon" (MUNRO, 2010, p. 700). Even if she casts some doubt on the accuracy of her recollection, all evidence seems to indicate that her father was not in the kitchen when her mother burned the bills.

From the narrator's perspective, the scene that she apparently made 
up embodies the love and understanding that characterized her parents' relationship in her opinion: "A solemn scene, but not crazy. People doing something that seems to them natural and necessary. At least one of them is doing what seems natural and necessary, and the other believes that the important thing is for that person to be free, to go ahead." (MUNRO, 2010, p. 701). Converted into a symbol of her ideal of love, this image becomes to her the truth (MUNRO, 2010, p. 701), which indicates that the meaning of this memory is more important for her than its factuality. The significance of this narrative for Fame is reinforced by the fact that she stops telling it when she believes that no one else understands it as a demonstration of the thoughtfulness that is essential for a relationship.

Fame's digging into her own memory focuses on love and relationships, both familial and marital. She believes that the bond between mother and daughter involves a burden of guilt and sometimes resentment, which may be observed in the following passage:

There was a cloud, a poison, that had touched my mother's life. And when I grieved my mother, I became a part of it. [...] it wasn't God, it was my mother I had to get straight with. It seemed as if she knew something about me that was worse, far worse, than ordinary lies and tricks and meanness; it was really a sickening shame. (MUNRO, 2010, p. 690)

In this way, the memory of Fame's mother, and indirectly of her grandmother, contributes to her own image of herself. This legacy, which Fame believes her brothers and sons do not share, is reinforced by the fact that she was named after her maternal grandmother. Her preference to be called Fame, rather than Euphemia, may be understood as an attempt to break this cycle.

As the title suggests, The Progress of Love also deals with the changes in relationships over time. Fame's grandparents' relation, though lasting through life, seemed to be marked by quarrels according to Beryl's description (MUNRO, 2010, p. 696), including even a possible suicide 
attempt. Fame, in turn, is divorced, which is regarded as something new - and not exactly positive - by her parents' generation (MUNRO, 2010, p. 685). However, she thinks that people in these new relationship arrangements may actually value and seek moments of reconciliation and kindness more than those in old marriages, in which "love and grudges could be growing underground" indefinitely (MUNRO, 2010, p. 701). Thus, the way Fame understands love and her own relationships is shaped by her memories - accurate or not - of her parents and the narratives that she has heard about her grandparents.

Margaret Atwood started her career as a writer in 1966, at the age of 27, and has published several poems, essays, short stories, and novels since then. Her works frequently criticize aspects of contemporary society, like consumerism and the influence of mass media. Atwood's concern with issues such as feminism and Canadian identity has an impact on her writing, which often has a political level (BENNET; BROWN, 2010, p. 811-812). Memory is an important question, especially in her later stories, which commonly feature characters who "move back and forth through time, revising their narratives of past experiences and finding new narratives for their futures" (RIDOUT, 2000, p. 853). Atwood herself expresses the crucial role of selection to the narrative of one's own story when discussing her novel Alias Grace (1996), inspired by a real nineteenth-century crime. According to the author, the late twentieth century is characterized by an "uneasiness about the trustworthiness of memory, the reliability of story" (ATWOOD, 1998, p. 1515), which suggests that she relates our recollections to storytelling.

The Age of Lead, published in Wilderness Tips (1991), revolves around the subject of memory as the protagonist, Jane, remembers her youth, focusing mainly on her relationship with a school friend called Vincent, who died less than a year before. Although the story is narrated in third person, it is told from Jane's point of view, taking readers through 
her version of the past. Her recollections are prompted by the discovery of the frozen corpse of a sailor who was part of the Franklin Expedition, a nineteenth-century voyage that attempted to find a sea passage from the Atlantic Ocean to the Pacific through the Arctic.

There are some similarities between the dead man found buried in ice and Vincent. Alice Ridout (2000, p. 866) points out that the description of Vincent in the hospital white room, covered with cold packs, resembles that of the frozen man. Ridout (2000, p. 866-867) also calls attention to the fact that both men died of unexplained reasons that may be related to the environment surrounding them. This parallel may be taken further since the scientific investigation of the cause of the sailor's death is echoed by Jane's own exploration of her past in search for answers or solace. In addition, as the memory of Vincent seems to pervade Jane's life, the following passage about the frozen man may be interpreted as referring to Vincent as well: "it's hard to know what tense should be applied to him, he is so insistently present" (ATWOOD, 2010, p. 833).

This insistent presence of Vincent in Jane's thoughts suggests an analogy between the dead explorer and memory itself. Both are marked by the idea of permanence since they represent vestiges of the past that endure in the present. However, while the corpse is preserved for a long period, it does not remain unchanged with the passage of time as the narrator mentions "the distortions caused by the ice" (ATWOOD, 2010, p. 833). In this way, the image of the frozen man mirrors memory in that it is a more permanent trace of the past without being unaltered or a completely faithful reproduction of what once was.

As Jane reminisces about Vincent and tries to make sense of their relationship, she seems frightened and disturbed, at least in part, due to his death. The nineteen eighties are described in the story as a moment of decay, marked by a visible increase in poverty. It is also a time when people "were dying too early" from a variety of diseases, and Jane notices 
recurrent news of environmental problems caused by human action, like acid rain, and pesticides in fruit and vegetables (ATWOOD, 2010, p. 840). Confronted with her own mortality, Jane is apparently overwhelmed by life. Whereas watching television used to be a means of escapism for her, now she thinks that even the commercials "look sinister" and the shows seem too similar to her life (ATWOOD, 2010, p. 833). In fact, her life is even messier than television since "nothing stays put in those tidy compartments, comedy here, seedy romance and sentimental tears there, accidents and violent deaths in thirty-second clips they call bites [...]. In her life, everything is mixed together" (ATWOOD, 2010, p. 833, original emphasis). Thus, Jane is upset and hopeless about the future when she remembers her past.

In addition to her bond with Vincent, Jane also remembers her mother and the difficult relationship between the two of them. Jane's mother got pregnant with her when she was single, and the father left them when the girl was five years old. As a consequence, her mother became suspicious of men in general, considering their desires to be a threat. As for Jane, she was regarded as "a mistake", "a crime that needed to be paid for, over and over" (ATWOOD, 2010, p. 835). Although Jane's mother sought to ingrain in her the need to distrust boys and avoid an unwanted pregnancy, she seemed to have an ambivalent feeling about her daughter's fate: "Jane's mother waited, fearfully and uttering warnings, but with a sort of gloating relish, for the same thing to happen to Jane" (ATWOOD, 2010, p. 836). Her mother seemed to feel that having her daughter follow the same path as her would, to an extent, diminish her feeling of guilt and inadequacy, probably because it would look less like an individual's fault than a common part of women's destiny. The short story makes it evident that men and women are judged by different standards that make sexual relations much riskier for girls (ATWOOD, 2010, p. 834) as they are the ones who are blamed and may become responsible for raising a child. 
However, Jane's view of her mother is not sympathetic since she is filled with resentment. For example, even though Jane is hurt about her father's leaving them, she does not blame him because "[h]er mother inspired in almost anyone who encountered her a vicious desire for escape" (ATWOOD, 2010, p. 835). Jane remembers her as a frustrated, unhappy woman who nostalgically looks back to her youth; however, she "comes up with [no pity]" for her mother even after so many years (ATWOOD, 2010, p. 835). Jane's resolution to distance herself from her mother's attitude is illustrated by her desire to have a child "without becoming a mother" (ATWOOD, 2010, p. 838), in other words, without carrying the same burden of bitterness.

Jane's exploration of her own memory leads her to assess her path through life. What Jane and Vincent wanted as teenagers was "freedom from the world of mothers, the world of precautions, the world of burdens and fate and heavy female constraints upon the flesh" (ATWOOD, 2010, p. 837). Their desire to prevent the past from repeating itself by being different from their parents is expressed in their delight to break social conventions and in their mockery of their mothers. Nevertheless, Vincent's death is a sign for Jane that " $[\mathrm{t}]$ heir mothers had finally caught up to them and been proven right. There were consequences to things you didn't even know you'd done" (ATWOOD, 2010, p. 841). Thus, the liberty and lightness that they hoped for seems to be unattainable, bringing Jane closer to the life that she wished to avoid. This point is reinforced by the following passage, which refers to Jane's state of mind in the present: "Laugh, I thought I'd die, Vincent used to say, a very long time ago, in a voice imitating the banality of mothers; and that's how it's getting to be" (ATWOOD, 2010, p. 833, original emphasis). Hence, Jane's distress about the present may be connected to the impression that her life has not followed the path that she had hoped.

It is relevant to take into account why Jane's relationship with 
Vincent has such an impact upon her sense of self and her evaluation of her own life. Firstly, Vincent is different from other men as he is the only one that she did not choose to leave. He is also the one she believed that she might have trusted when she was younger (ATWOOD, 2010, p. 838). Vincent's uniqueness may be related to the fact that he symbolized, for Jane, freedom from constraints, embodying the antithesis of what her mother represented. However, having such a deep attachment to someone means being susceptible to the suffering of losing this person. Thus, Jane cannot escape the heaviness of loss - or the steamroller that was love (ATWOOD, 2010, p. 836) - after all.

In sum, the three short stories under discussion represent memory as something flexible, subjected to processes of selection, interpretation, and variation through time. These literary works also illustrate the possibility of different versions of the same event and other people's potential influence on our recollections. As the protagonists remember the past, they also construct a narrative of their lives that affects their image of themselves and others. Hence, even if memory is intrinsically related to the past, its repercussions in the present are undeniable, living on through different generations.

\section{References:}

ARISTOTLE. From De Memoria et Reminiscentia. In: ROSSINGTON, Michael; WHITEHEAD, Anne (ed.). Theories of Memory: A Reader. Edinburgh: Edinburgh University Press, 2007. p. 28-38.

ATWOOD, Margaret. In Search of Alias Grace: On Writing Canadian Historical Fiction. The American Historical Review, Oxford, v. 103, n. 5, p. 1503-1516, Dec. 1998. Available at: http://www.jstor.org/stable/2649966. Accessed: Feb. 21, 2018. DOI: 10.2307/2649966.

. The Age of Lead. In: BENNET, Donna; BROWN, Russell 
(ed.). An Anthology of Canadian Literature in English. Oxford: Oxford University Press, 2010. p. 832-842.

BENNET, Donna; BROWN, Russell (ed.). An Anthology of Canadian Literature in English. Oxford: Oxford University Press, 2010.

BERGSON, Henri. From Matter and Memory. In: ROSSINGTON, Michael; WHITEHEAD, Anne (ed.). Theories of Memory: A Reader. Edinburgh: Edinburgh University Press, 2007. p. 109-113.

BRUCKNER, Donald J. R. An Author Travels to Nurture Ideas About Home [an interview with Alice Munro]. The New York Times, New York, 17 Apr. 1990. Books. Available at: https://www.nytimes.com/1990/04/17/ books/an-author-travels-to-nurture-ideas-about-home.html. Accessed: Feb. 21, 2018.

CANDAU, Joël. Memória e identidade. São Paulo: Editora Contexto, 2016.

EAKIN, Paul John. Living Autobiographically: How We Create Identity in Narrative. Ithaca: Cornell University Press, 2008.

FRANCESCONI, Sabrina. Memory and Desire in Alice Munro's Stories. Textus, Bologna, v. 22, n. 2, p. 341-359, Jan. 2009. Available at: https:// www.researchgate.net/publication/320383297_Memory_and_Desire in Alice Munro's Stories. Accessed: Feb. 21, 2018.

FREUD, Sigmund. A Note upon the 'Mystic Writing-Pad'. In: ROSSINGTON, Michael; WHITEHEAD, Anne (ed.). Theories of Memory: A Reader. Edinburgh: Edinburgh University Press, 2007. p. 114-118.

GRACE, Sherrill E. Crossing Jordan: Time and Memory in the Fiction of Margaret Laurence. World Literature Written in English, Abingdon, v. 16 , n. 2 , p. $328-339,1977$. Available at: https://www.tandfonline.com/ doi/citedby/10.1080/17449857708588471. Accessed: Feb. 21, 2018. DOI: $10.1080 / 17449857708588471$.

HALBWACHS, Maurice. A memória coletiva. São Paulo: Centauro, 2006. HUA, Anh. Diaspora and Cultural Memory. In: AGNEW, Vijay (ed.). 
Diaspora, Memory, and Identity: A Search for Home. Toronto: University of Toronto Press, 2008. p. 191-208.

KUHN, Annette. From Family Secrets: Acts of Memory and Imagination. In: ROSSINGTON, Michael; WHITEHEAD, Anne (ed.). Theories of Memory: A Reader. Edinburgh: Edinburgh University Press, 2007. p. 230235.

LAURENCE, Margaret. To Set Our House in Order. In: BENNET, Donna; BROWN, Russell (ed.). An Anthology of Canadian Literature in English. Oxford: Oxford University Press, 2010. p. 609-620.

MUNRO, Alice. The Progress of Love. In: BENNET, Donna; BROWN, Russell (ed.). An Anthology of Canadian Literature in English. Oxford: Oxford University Press, 2010. p. 683-701. . The View from Castle Rock. London: Vintage, 2007.

PLATO. From Theaetetus and Phaedrus. In: ROSSINGTON, Michael; WHITEHEAD, Anne (ed.). Theories of Memory: A Reader. Edinburgh: Edinburgh University Press, 2007. p. 25-27.

RIDOUT, Alice. Temporality and Margaret Atwood. University of Toronto Quarterly, Toronto, v. 69, n. 4, p. 849-870, Fall 2000. Available at: https://www.utpjournals.press/doi/abs/10.3138/utq.69.4.849?.journalCode=utq. Accessed: Feb. 21, 2018. DOI: 10.3138/utq.69.4.849.

Recebido em: 21/05/2020

Aprovado em: 24/06/2020 


\section{Resenhas}

Poesia no mundo 